\title{
SYSTEM OF DIGITAL CRITERIA FOR EDUCATIONAL WEB RESOURCE ASSESSMENT
}

\author{
Valentina Aleksandrovna Solovyova ${ }^{1}$
}

\begin{abstract}
An educational web resource is a tool that can help discern useful data on the Internet. A system of criteria, however, is needed to assess the quality of this resource. Existing assessment models use various principles for this purpose. Ten such models are considered in this paper, though none of these use the basic principles of education. This paper suggests a unique new model that considers the major pedagogical principles of scientific content, visualization, the availability and feasibility of education, humanization of education, and students' consciousness and participation. These principles are modified for the requirements of e-learning. The main focus of creating the model is the learner. Some assessment-related points in the suggested model are described in a more detailed manner than in previous models. The new model provides criteria that can ensure the quality of an educational Web resource. Thus, the model can form the foundation for creating educational resources.
\end{abstract}

UDC Classification: 37.02 ; DOI: http://dx.doi.org/10.12955/cbup.v5.1032

Keywords: educational, Web, resource, quality, assessment, digital, criteria, e-learning

\section{Introduction}

Such terms as information environment, post-industrial society, information society, information era, and ZettaByte epoch are frequently used to describe today's era. The cause includes at least these two reasons:

- The volume of digital information doubles on average every eighteen months; and

- The global IP traffic is set to overpass a ZettaByte $\left(10^{21}\right.$ bit $)$ and increase annually in the future, as stated by the 2015-2016 Cisco Visual Networking Index Forecast and Methodology report.

These scenarios reflect the increase in generated information volume and growth of its use on the net and give rise to certain problems. It is becoming more difficult for an individual to discern useful data and information overload is increasing, which leads to intellectual 'stroke' (a term used to describe the state of 'numbness' due to information and knowledge overload; Shrayberg, 2016).

This problem is especially interconnected with education, mostly as education involves extremely complicated tasks because of widespread information and technology (IT) development. For example, the digitizing of knowledge that requires mechanisms to facilitate the use of online information and to enable an individual to both use and critically assess such large amounts of data.

One tool that can help solve such problems is an educational Web resource. When used correctly it can provide many advantages to all participants of education (Krelja Kurelovic, 2016; Hilton, 2016; Bacsich, Pepler, Bristow, Ossiannilsson, Creelman, Szalma \& Slaidins, 2015). Thus, there is a need to understand whether an educational Web resource is used or created correctly. One possible way could be to assess its quality by way of a comprehensive analysis of its advantages and effectiveness of the operation.

Assessing the quality of a Web resource requires a system of criteria. Classical models for assessing the quality of educational Web resources (e.g., paper textbooks) are counter-productive for two reasons:

- Students' way of thinking changes, therefore, the type of presentation should change also, and

- The functioning of an online web resource changes the perception of information.

This paper reports on a new model of assessing the quality of educational Web resources that is based on an analysis of existing models but which incorporates a system using the basic principles of education.

\footnotetext{
${ }^{1}$ Postgraduate Student, Faculty of Nano- and Biomedical Technologies, Saratov State University, Russia, v.a.solovyova@gmail.com
} 


\section{Literature Review}

In the scientific sources of literature, 10 models for assessing the quality of an educational Web resource were found. These involved various principles, standards, or groups of criteria for specifics unrelated to the course of work chosen for this current study. For example, for estimating the quality of a Web source, Joo, Lin, and Lu (2011) proposed a model based on three subscales: effectiveness, efficiency, and learnability. A model by Toleva-Stoimenova and Christozov (2013) used a similar set of three criteria: effectiveness, efficiency, and user satisfaction.

Polillo (2011) proposed to evaluate an educational Web-source with these characteristics: architecture, communication, functionality, content, community, platform, accessibility, usability (external quality and quality), and usability (internal quality).

According to Jabar, Usman, and Awal (2013), such an evaluation should use factors of attractiveness, controllability, helpfulness, efficiency, and learnability. Under Hasan (2014) the appraisal includes categories of navigation, organization or architecture, ease of use for communicating, design, and content.

Other analyzed models were based on dimensions of content, navigability, structure or design, the appearance of multimedia, and personalization (Matas, 2014). Another was on maintaining current educational resources, enhancing the learning environment, providing quality assurance mechanisms, and aligning open educational resources (OER) to common standards (Orr et al., 2015). Pow and Li (2015) used these groups: perceived usefulness, actual usefulness, perceived ease of use, and actual ease of use. Criteria of authority, update, usability, accessibility, communication, graphic design and multimedia quality, content, navigation, and the speed of access and interaction were used by Santos (2016), and eight general standards were proposed by Lowenthal and Hodges (2015).

Notably, most of these models offer similar criteria for evaluating a resource. Figure 1 shows the different criteria and their frequency of use across the 10 assessment models.

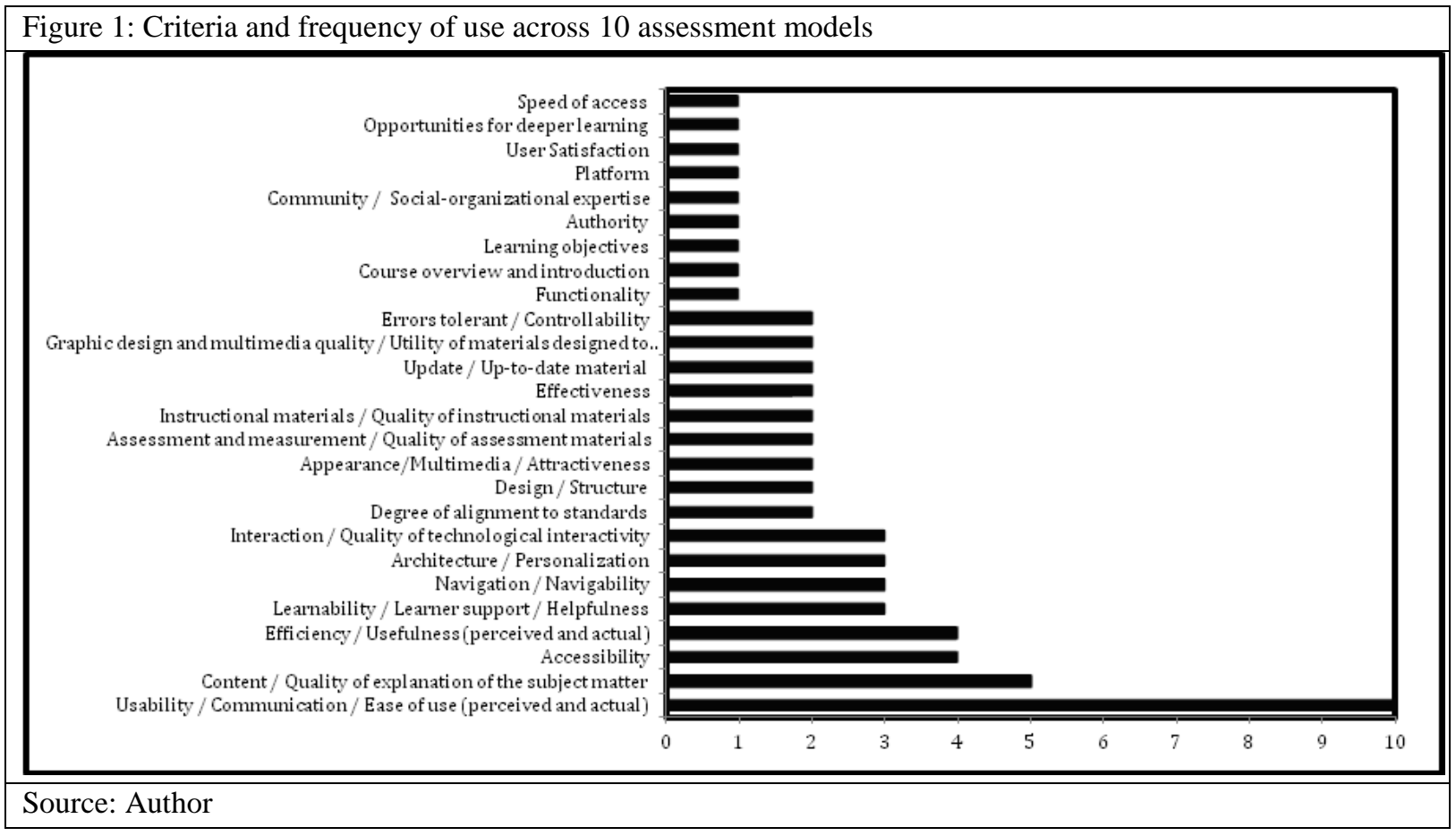

\section{Data and Methodology}

The system of criteria proposed by this current study was based on aligning the educational Web resource with the major educational principles. This decision was justified by a need to achieve a pedagogical effect when using educational Web resources. The analysis identified five major educational principles:

1. Scientific content,

2. Visualization, 
3. Availability and feasibility of education, and

4. Humanization of education.

5. Students' consciousness and participation.

These principles were used to discern the digital criteria and to provide insight with consideration to the specifics of e-learning.

The principle of scientific content corresponds to accuracy and correctness of the educational information available to learners and needs to contain scientific facts and knowledge. The following criteria were formulated for the principle of scientific content:

- Scientific feasibility.

- Lack of factual mistakes.

- Lack of unethical information.

- Compliance with the syllabus (in case the Web resource is a part of an educational program).

- Completeness of the subject under study, e.g., the number of didactic units, which have to be included to cover the topic and their proportion against the total number of didactic units.

- Additional materials, i.e., useful links related to the topic and educational material available for downloading (textbooks, articles, and books).

Web page content requires constant verification and updating for authenticity, and thus, timely visualization was another criterion identified as influencing the quality of an educational resource.

The principle of visualization corresponds to the possibility of educational material perceived using several sense organs. Visualization of the material is a tool for improving a learners' memory (e.g., infographic, animation, video, mind maps and interactive maps, diagrams, charts, photographs, and pictures). In addition, relevant program segments are benchmarks, as Barthes (1977) stated, "Almost all images, in all contexts, are accompanied by some linguistic message. This seems to have two possible functions: anchorage and relay". Thus, appropriate matching of text and visual material provided a possible and prominent pedagogical effect.

The principle of visualization was developed in the works of such prominent classical educator as Comenius (1697). Pestalozzi also considered visual thinking to be one of the most powerful features of the mind, and believed that imagery was the start of all knowledge (as cited in Webster, 2005). The expediency of using multimedia technologies was also substantiated in the works of modern researchers (Ilhan, \& Oruç, 2016; Kilonzo, Sandfort, \& Liu, 2016; Tang, 2016).

Setting this principle as being crucial for Internet information was considered appropriate as students' use of the educational Web resource is neither supervised nor accompanied by teacher explanations.

It was assumed that an effective educational Web resource required the following:

- Appropriate data submission for audio, video, graphic educational materials (and their combinations); and

- A suitable balance of visual and text material to strengthen the educational impact of the resource.

In respect to principle availability and feasibility of education, it was deemed that educational material should be presented gradually and logically. Considering the intellectual potential of learners, their age-related peculiarities, and current knowledge status discerned the following three requirements:

1. Material should be thoroughly planned, divided into completed sections (if it does not contradict the selected educational method), possess the ideological center as well as basic concepts that form the content of the resource. Each information section should be accompanied by a glossary and abstract (commentary). Optimal sequence of educational material presented on the Web page has to be defined, i.e., information text blocks and visual material has to be logically positioned so that they attract the attention of the potential learner;

2. One has to take into consideration the various teaching materials necessary for creating an educational Web resource. An overabundance of material, as well as a deficit, leads to a loss of students' concentration. Therefore, the aim is to define the optimal quantity of didactic units (such as theorems, methods, rules, and laws) and explain units (properties and characteristics) for the Web resource; and 
3. Because the Internet provides extensive opportunities for logical transitions between interconnected blocks of information, one has to define the logic of using links and hyperlinks in the text.

For assessing the effectiveness of using the principle of availability and feasibility of education, the following criteria were selected:

- The complexity of material

- A number of didactic and explaining units collocated to the speed of information processing by a human (e.g., reading $18-45$ byte per second);

- The number of hyperlinks in the text; and

- Reference information.

An example application for complexity of material is the Flesh-Kinkaid Score (Venig \& Solovyova, 2016),

The principle of humanization of education may be denoted as one that creates user-friendly conditions for students' education. This principle was substantiated as the fundamental principle for the education environment in the works of outstanding educators of Ancient Rome (Quintilian and Cicero) and later was developed in the works of educators of the Renaissance as Campanella (1981). Modern research also indicates actuality and feasibility of this principle's application (Zarevski, 2015; Gilad, 2015).

With regards to e-learning, this principle involved several requirements.

The first requirement involved creating accessibility features in the resource for the Internet user. Primarily, this principle interconnects with the peculiarities of how educational material functions in the Internet environment and creates a user-friendly environment. This implied the following:

- Creating the opportunity to work with the source for students with disabilities. In this case, it means designing the version for visually-impaired users;

- Providing an opportunity to connect with the Web source from any device; from smartphones and tablets to laptops and computers (adaptable layout);

- Providing a fast 'boot' of the Web page and high downloading speed;

- Securing resistance to erroneous and incorrect user actions;

- Limiting annoying advertising;

- Limiting broken links to pages, documents, and images;

- Using easy formalization of text (font size, line spacing);

- Using high-quality multimedia material (definition); and

- The correctness of text data.

The second requirement related to the influence of e-learning on a student's personality. The digital material should provoke the feeling of emotional and psychological security in a learner. These are the psychological and pedagogical requirements. The criteria that were distinguished here are the availability of feedback (individual information support) and timely error correction by the Web resource developers in response to users' complaints.

The third requirement involved the criterion of data update and the manner of its presentation, especially, for assessing the quality of the Web resource. It was important to consider the peculiarities of modern learners' perceptions and their thinking as a 'Web surfer.' Because there is a large amount of educational and other types of material, a learner skims through web pages in the course of two to three seconds to identify whether they will use that specific resource. Therefore, it was necessary to define how the attention span of a student is met in order to choose the most suitable structure of information arrangement on the website. Major requirements for headings, text, and graphics location of the pedagogical design should form the foundation of an educational Web page design.

Another pedagogical principle that was identified is the principle of student's consciousness and participation. It does not presume the order of information presentation, but rather the way data collection relates to the effectiveness of implementing the four principles described above. Assessment of implementing this principle is possible by evaluating the visiting statistics of the Web source, as well as the target actions on the Web page, such as downloads of videos and audios, and clicking on hyperlinks. Basic parameters of Google Analytics, e.g., the average duration of page views and the 
number of downloads can be used to fulfill this task. These indicators would be adapted to the specifics of every web page, for example:

- Average duration of a page view correlated with data size of page contents;

- A number of downloads correlated with data size of the page content.

\section{Results and Discussion}

The results of analyzing didactic requirements provided a system of digital criteria for assessing the content of an educational Web source. All criteria discerned were systematized into corresponding sub-groups (Table 1).

It should be noted that these criteria reflect the analysis from the perspective of one participant's educational needs only, i.e. the learner's. Viewing the Web resource design from the perspective of an educator or developer requires an extra important criterion, i.e., the amount of time or money spent on the development of an educational Web resource.

Table 1: System of digital criteria for educational Web resource assessment

\begin{tabular}{|c|c|c|c|}
\hline $\begin{array}{c}\text { Indicators of scientific } \\
\text { and educational } \\
\text { feasibility }\end{array}$ & User characteristics & $\begin{array}{l}\text { Information and } \\
\text { Technological } \\
\text { characteristics }\end{array}$ & Indicators of source use \\
\hline $\begin{array}{l}\text { 1. Scientific feasibility } \\
\text { 2. A number of factual } \\
\text { mistakes } \\
\text { 3. Correspondence with } \\
\text { the syllabus } \\
\text { 4. Completeness of } \\
\text { topic under study } \\
\text { 5. Availability of } \\
\text { downloadable } \\
\text { educational material } \\
\text { 6. A number of useful } \\
\text { links } \\
\text { 7. Lack of unethical } \\
\text { information } \\
\text { 8. Availability of a } \\
\text { glossary and abstract } \\
\text { 9. Availability of video } \\
\text { and audio materials } \\
\text { related to the topic } \\
\text { under study } \\
\text { 10. Availability of } \\
\text { supporting materials } \\
\text { (illustrations, graphs, } \\
\text { tables) } \\
\text { 11. Required volume of } \\
\text { didactic units of the } \\
\text { material presented } \\
\text { 12. The difficulty level } \\
\text { of educational } \\
\text { material }\end{array}$ & $\begin{array}{l}\text { 1.Ergonomic index (convenience of } \\
\text { use) included: } \\
\text { - Availability of a version for } \\
\text { visually impaired learners } \\
\text { - Easy access from various } \\
\text { gadgets (PC, tablet, } \\
\text { smartphone) } \\
\text { - The correctness of text data } \\
\text { (number of punctuation, } \\
\text { syntactic and semantic } \\
\text { mistakes) } \\
\text { - The balance between text and } \\
\text { visual material } \\
\text { - Utilization of user-friendly } \\
\text { information presentation (the } \\
\text { F-effect rule) } \\
\text { - Lack of irritating } \\
\text { advertisements } \\
\text { Availability of feedback } \\
\text { - The orderliness of text and } \\
\text { graphic elements (font size, } \\
\text { highlighting, line length) } \\
\text { - The quality of multimedia } \\
\text { material used (picture } \\
\text { definition, audio, and video } \\
\text { materials' bitrate) } \\
\text { 2.Esthetic index included the color } \\
\text { design of the Web resource } \\
\text { (utilization of Web design rules). } \\
\text { 3. Timely correction of system errors } \\
\text { upon users' request. }\end{array}$ & $\begin{array}{l}\text { 1. Adaptive page } \\
\text { layout } \\
\text { 2. Average page } \\
\text { loading time } \\
\text { 3. Average } \\
\text { multimedia } \\
\text { file loading } \\
\text { time } \\
\text { 4. Average } \\
\text { material } \\
\text { downloading } \\
\text { time } \\
\text { 5. The number of } \\
\text { broken links } \\
\text { (to non- } \\
\text { existent pages, } \\
\text { documents, } \\
\text { images) } \\
\text { 6. Availability of } \\
\text { text hyperlinks } \\
\text { 7. Resistance to } \\
\text { misleading and } \\
\text { incorrect user } \\
\text { actions } \\
\text { 8. The average } \\
\text { server response } \\
\text { time }\end{array}$ & $\begin{array}{l}\text { 1. Estimated average } \\
\text { number of page views } \\
\text { (defining the potential } \\
\text { user audience) over a } \\
\text { certain period (for } \\
\text { comparison with the } \\
\text { following } \\
\text { characteristics) } \\
\text { 2. The number of page } \\
\text { views } \\
\text { 3. The number of unique } \\
\text { page views } \\
\text { 4. The average duration of } \\
\text { a page view (in } \\
\text { correspondence with } \\
\text { data volume available } \\
\text { on the Web resource) } \\
\text { 5. Copying content } \\
\text { elements to the } \\
\text { clipboard } \\
\text { 6. Navigation } \\
\text { 7. Image scaling for more } \\
\text { precise viewing } \\
\text { 8. Conversion (following } \\
\text { the links; downloading } \\
\text { files; video viewing; } \\
\text { listening to the audio } \\
\text { files) }\end{array}$ \\
\hline \multicolumn{3}{|c|}{ - Timely update of materials and material presentation methods } & \\
\hline
\end{tabular}

This nomenclature may be expanded for specific tasks and needs in the course of creating the educational Web resource. Table 2 features the comparison of criteria of eleven analyzed assessment models and the unique model formulated in this present study. 
Table 2: Comparison the criteria of the developed model with other models

\begin{tabular}{|c|c|c|}
\hline No & Combined Criteria of 10 Existing Models & Criteria of the Proposed Assessment System \\
\hline 1 & $\begin{array}{l}\text { Usability / Communication / Ease of use } \\
\text { (perceived and actual) }\end{array}$ & \multirow[t]{3}{*}{ User characteristics } \\
\hline 2 & Design / Structure & \\
\hline 3 & Accessibility & \\
\hline 4 & $\begin{array}{l}\text { Content / Quality of explanation of the subject } \\
\text { matter / Quality of practical exercises }\end{array}$ & Indicators of scientific and educational feasibility \\
\hline 5 & Efficiency / Usefulness (perceived and actual) & $\begin{array}{l}\text { Scientific feasibility + Convenience of text manipulation } \\
\text { (font size, highlighting, line length). }\end{array}$ \\
\hline 6 & Learnability / Learner support / Helpfulness & $\begin{array}{l}\text { Availability of glossary and abstract. } \\
\text { Availability of feedback. }\end{array}$ \\
\hline 7 & Navigation / Navigability & Hypertext links. \\
\hline 8 & $\begin{array}{l}\text { Interaction / Quality of technological interactivity } \\
\text { / Learner interaction and engagement / } \\
\text { Compatibility }\end{array}$ & $\begin{array}{l}\text { Partially: hypertext links, availability of subject-related } \\
\text { video and audio materials, availability of supporting data } \\
\text { (illustrations, graphs, tables), availability of educational } \\
\text { material for downloading, number of useful links. }\end{array}$ \\
\hline 9 & Appearance / Multimedia / Attractiveness & $\begin{array}{l}\text { Availability of subject video and audio materials on the } \\
\text { topic under study. } \\
\text { Availability of supporting data (illustrations, graphs, tables). } \\
\text { Quality of used multimedia materials (picture definition, } \\
\text { audio, and video materials' bitrate). }\end{array}$ \\
\hline 10 & Architecture / Personalization & \multirow{5}{*}{$\begin{array}{l}\text { These criteria have not been considered in the present } \\
\text { model because the goal of the model is to assess the quality } \\
\text { of the educational page only, not the quality of the complete } \\
\text { electronic educational resource. }\end{array}$} \\
\hline 11 & Degree of alignment to standards & \\
\hline 12 & $\begin{array}{l}\text { Assessment and measurement / Quality of } \\
\text { assessment materials }\end{array}$ & \\
\hline 13 & Opportunities for deeper learning & \\
\hline 14 & $\begin{array}{l}\text { Instructional materials / Quality of instructional } \\
\text { materials }\end{array}$ & \\
\hline 15 & Errors tolerant / Controllability & Resistance to misleading and incorrect user actions. \\
\hline 16 & Effectiveness & $\begin{array}{l}\text { This criterion is similar to the group called Indicators of } \\
\text { source use. However, it ignores the criterion called "time } \\
\text { spent on the creation of the resource." }\end{array}$ \\
\hline 17 & Update / Up-to-date material & $\begin{array}{l}\text { Timely update of material and methods of material } \\
\text { presentation }\end{array}$ \\
\hline 18 & $\begin{array}{l}\text { Graphic design and multimedia quality. Utility of } \\
\text { materials designed to support teaching }\end{array}$ & $\begin{array}{l}\text { Quality of used multimedia materials (picture definition, } \\
\text { audio, and video materials' bitrate). }\end{array}$ \\
\hline 19 & Functionality & \multirow[t]{2}{*}{ Information and Technological characteristics } \\
\hline 20 & Platform & \\
\hline 21 & Course overview and introduction & Partly: Availability of glossary and abstract. \\
\hline 22 & Learning objectives & $\begin{array}{l}\text { This criterion implies correspondence with the education } \\
\text { principle: availability and feasibility }\end{array}$ \\
\hline 23 & Authority & $\begin{array}{l}\text { The Web site creator authority matters, but in the present } \\
\text { model, primary attention has been paid to content } \\
\text { assessment because the content quality is undoubtedly } \\
\text { interconnected with Web developer's professionalism. }\end{array}$ \\
\hline 24 & Community / Social-organizational expertise & $\begin{array}{l}\text { This criterion has not been considered yet and will be } \\
\text { viewed at the next stage of the present study. }\end{array}$ \\
\hline 25 & User Satisfaction & Indicators of source use \\
\hline 26 & Speed of access & Average page loading time. \\
\hline
\end{tabular}




\section{Conclusion}

The major aim of this study was to develop a model to assess the quality of an educational Web resource from the point of view of its main user, the learner. The need for the model emerged because certain criteria had not been considered in previous models. In this regard, some of the assessmentrelated points have been described in more detail than in the previous models. The present work can be used for discerning criteria that form the foundation of an educational resource. Considering the quality of an educational resource influences the quality of education in general, ensuring Web resource quality is a priority for the educational community.

\section{References}

Bacsich, P., Pepler G., Bristow S.F., Ossiannilsson E., Creelman A., Szalma E. \& Slaidins I. (2015) Research For Cult Committee - Adult Education And Open Educational Resources. Study. Retrieved from http://www.europarl.europa.eu/RegData/etudes/STUD/2015/563397/IPOL_STU(2015)563397_EN.pdf

Barthes, R. (1977) Image Music Text. Hammersmith, London: Fontana Press.

Campanella T. (1981). The City of the Sun. Transl. DJ Donno. Berkeley, CA: Univ. Calif. Press. (Original work published 1602).

Comenius, J. A., \& Keatinge, M. W. (1967). The great didactic of John Amos Comenius. New York: Russell \& Russell. (Original work published 1875).

Gilad, E. (2015) The Humanistic Education in a Unique Pre-Service Teacher Education Program for Ethiopian Immigrants: A Foundation for Bridging Gaps. International Journal for Innovation Education and Research, 3(7), 115-125.

Hasan, L. (2014) Evaluating the Usability of Educational Websites Based on Students' Preferences of Design Characteristics. International Arab Journal of e-Technology, 3(3), 179-193.

Hilton, J. (2016) Open educational resources and college textbook choices: a review of research on efficacy and perceptions. Education Tech Research Dev, 64, 573-590. https://doi.org/10.1007/s11423-016-9434-9

Ilhan, G.O., Oruç, Ş. (2016) Effect of the use of multimedia on students' performance: A case study of social studies class. Educational Research and Reviews, 11(8), 877-882. DOI:10.5897/ERR2016.2741

Jabar, M.A., Usman, A.U., \& Awal, A. (2013) Assessing The Usability Of University Websites From Users' Perspective. Australian Journal of Basic and Applied Sciences, 7(10), 98-111.

Joo, S., Lin, S., \& Lu, K. (2011) A Usability Evaluation Model for Academic Library Websites: Efficiency, Effectiveness and Learnability. Journal of Library and Information Studies, 9(2), 11-26.

Kilonzo, S.M., Sandfort, J.R., Liu, H.K. (2016) Using Multimedia Learning Objects in Public Affairs Classrooms: Global Experiences With Hubert Project E-Cases and E-Studies. Journal of Public Affairs Education, 22(3), 345-362.

Krelja Kurelovic, E. (2016). Advantages and limitations of usage of open educational resources in small countries. International Journal of Research in Education and Science (IJRES), 2(1), 136-142. https://doi.org/10.21890/ijres.92299 Lowenthal, P.R., \& Hodges, C.B. (2015) In Search of Quality: Using Quality Matters to Analyze the Quality of Massive, Open, Online Courses (MOOCs). The International Review of Research in Open and Distributed Learning, 16(5), 83-101. https://doi.org/10.19173/irrodl.v16i5.2348

Matas, A. (2014) A website quality assessment framework for educational websites: prioritizing the criteria. Master's thesis. University of Macedonia, Thessaloniki. Retrieved from http://dspace.lib.uom.gr/handle/2159/17545.

Orr, D., Rimini, M., \& Van Damme, D. (2015) Open Educational Resources: A Catalyst for Innovation. OECD Publishing, Paris. https://doi.org/10.1787/9789264247543-en

Polillo, R. (2011) Quality Models for Web [2.0] Sites: a Methodological Approach and a Proposal. Proceedings of the 11th International conference on Current Trends in Web Engineering, June 20-21, 2011, Paphos, Cyprus (pp. 251-265). Berlin Heidelberg: Springer-Verlag. DOI:10.1007/978-3-642-27997-3_25

Pow J, \& Li, C.S. (2015) The effect of students' perceptions of Internet information quality on their use of Internet information in inquiry-based learning. Australasian Journal of Educational Technology, 31(4), 439-457.

https://doi.org/10.14742/ajet.1936

Santos, M.A. (2016) Theoretical-Methodological proposal to evaluate the quality of educational web sites to support education [Powerpoint slides]. Retrieved from http://www.slideshare.net/teemconference/theoreticalmethodologicalproposal-to-evaluate-the-quality-of-educational-web-sites-to-support-education

Shrayberg, Y. (2016) Time for changes: Global information trends and prospects. Scientific and Technical Libraries, 9, 3-56. Tang, S. (2016) Digital Storytelling Approach in a Multimedia Feature Writing Course. Journal of Language Teaching and Research, 7(3), 572-578. https://doi.org/10.17507/jltr.0703.19

Toleva-Stoimenova, S., \& Christozov, D. (2013) Informing via Websites: Comparative Assessment of University Websites. Issues in Informing Science and Information Technology. 10, 525-537.

Venig, S.B., \& Solovyova, V.A. (2016) Eye-tracking: regularities of educational information searching. International Annual Edition of Applied Psychology: Theory, Research, and Practice, 3(1), 97-111. Retrieved from http://interpsy.sgu.ru/sites/default/files/9._eye-tracking_regularities_of_educational_information_searching.pdf

Webster, R. (2005) Creative Visualization for Beginners. Woodbury, Minnesota: Llewellyn Publucations.

Zarevski, D. (2015) Role of educational policies and philosophical thought on education in building functional, stable and prosperous knowledge society. New Balkan politics. Journal of Politics, 17, 51-69. 